\title{
The Effect of Red Seaweed (Kappaphycus alvarezii) Biscuits on Hemoglobin Levels and Body Weight among the First Trimester Pregnant Women
}

\author{
Salma Salma ${ }^{1 *}$, Veni Hadju² ${ }^{2}$, Jamaluddin Jompa $^{3} \mathbb{D}$, Stang Stang ${ }^{4}$, Sundari Sundari ${ }^{5}$, Andi Nilawati Usman ${ }^{6}$ \\ ${ }^{1}$ Midwifery Study Program, Graduate School, Hasanuddin University, Makassar, Indonesia; ${ }^{2}$ Department of Nutrition, Faculty of \\ Public Health, Hasanuddin University, Makassar, Indonesia; ${ }^{3}$ Department of Marine Science, Faculty of Marine and Fisheries \\ Sciences, Hasanuddin University, Makassar, Indonesia; ${ }^{4}$ Department of Biostatistic, Faculty of Public Health, Hasanuddin \\ University, Makassar, Indonesia; ${ }^{5}$ Midwifery Diploma Program, Faculty of Public Health, Indonesian Muslim University, \\ Makassar, Indonesia; ${ }^{6}$ Department of Midwifery, Graduate School, Hasanuddin University, Makassar, Indonesia
}

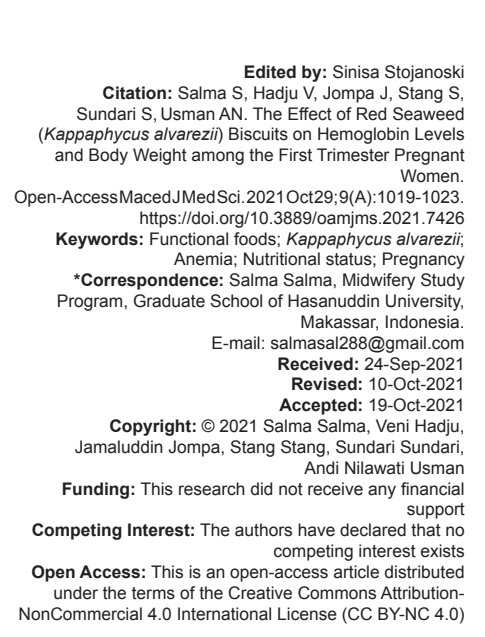

\section{Abstract}

BACKGROUND: The prevalence of anemic pregnant women is still reasonably high, especially in low-middleincome countries.

AIM: This study was aimed to assess the effect of giving red seaweed (Kappaphycus alvarezii) biscuits on changes in hemoglobin $(\mathrm{Hb})$ levels and body weight of pregnant women in the first trimester.

METHODS: The study used a quasi-experiment pretest-posttest study design. The study was conducted from April to June 2021 involving pregnant women in the first trimester who living in the working area of the Wapunto Community Health Center, Muna Regency, Indonesia. A total of 45 pregnant women were selected purposively and assigned to three different groups. The first group was given two pieces of red seaweed biscuits per day. The second group was given two pieces of red seaweed biscuits plus Fe tablets $(60 \mathrm{mg} / \mathrm{day})$, and the last group was given Fe tablet only (60 mg/day). Chi-square, paired sample t-test, Wilcoxon, and Kruskal-Wallis tests were performed using SPSS.

RESULTS: The intervention group of red seaweed biscuits plus Fe tablets had the highest increase in $\mathrm{Hb}$ levels after 8 weeks of intervention, followed by the red seaweed biscuit group and the control group $(0.97,0.78$, and $0.60 \mathrm{~g} / \mathrm{dL}$, respectively, $\mathrm{p}$-value $<0.05)$. The red seaweed biscuit intervention group had the highest changes for body weight compared to the red seaweed biscuit plus Fe tablet group and the control group $(1.07,0.43$, and $0.04 \mathrm{~kg}$, respectively).

CONCLUSION: The provision of red seaweed biscuits could increase maternal $\mathrm{Hb}$ level and weight during the first trimester of their pregnancy.

\section{Introduction}

Low hemoglobin $(\mathrm{Hb})$ levels are one of the causes of anemia. According to the WHO, the incidence of anemia in pregnant women worldwide is $41.8 \%$. In Indonesia, based on the Basic Health Research (RISKESDAS) results in 2013, the prevalence of anemia among pregnant women was $37.1 \%$. This figure was even higher 5 years later reaching $48.9 \%$. Therefore, special attention is required for the prevention.

Anemia in pregnant women can be classified into four levels of severity: Not anemia with the $\mathrm{Hb}$ value $>11 \mathrm{~g} / \mathrm{dL}$, mild anemia $(9-10 \mathrm{~g} / \mathrm{dL})$, moderate anemia (7-8 $\mathrm{g} / \mathrm{dL})$, and severe anemia with $\mathrm{Hb}$ value $<7 \mathrm{~g} / \mathrm{dL}$ [1]. Anemia in pregnant women is caused by iron deficiency, folic acid deficiency, infections, and blood disorders [2]. Foods containing sufficient iron, yet with low bioavailability, can cause less iron to be absorbed [3]. The consequences of anemia in pregnant women are miscarriage, premature delivery, the inhibition of fetal growth and development in the womb, susceptibility to infection, antepartum bleeding, and premature rupture of membranes [4].

Until recently, the Indonesian government has implemented an anemia control program for pregnant women, including providing a minimum of $90 \mathrm{Fe}$ tablets during pregnancy. However, the incidence of anemia is still relatively high [5]. This is caused by the common practices and the lack of self-discipline in the community, as evidenced by the number of pregnant women who do not consume Fe tablets regularly, limited access to health services, weak family support, myths about the side effects of Fe tablets that trigger a reluctance to consume these tablets, and the lack of understanding and knowledge to meet the nutritional needs during pregnancy [6].

Seaweed is a food with great bioavailability for better iron absorption, containing several compounds necessary for hemoglobin synthesis [7]. In general, 
seaweed grows at a depth through which sunlight can still penetrate [8]. According to the United Nation Convention on the Law of the Sea in 1982, Indonesia's waters cover 5.8 million $\mathrm{km} 2$, in which $27.2 \%$ of the world's flora and fauna species live. Furthermore, data from the Food and Agriculture Organization [9] show that Indonesia is one of the largest seaweed-producing countries worldwide, and even ranked $2^{\text {nd }}$ after China in 2013 [10]. Red seaweeds (Kappaphycus alvarezii) are a source of pro-Vitamin A, Vitamin B1, Vitamin B2, Vitamin B6, Vitamin B12, Vitamin C, Vitamin D, Vitamin $\mathrm{E}$, and Vitamin $\mathrm{K}$, as well as potassium, calcium, phosphorus, sodium, iron, and iodine. Red seaweeds contain more iron, dietary fiber, vitamins, and minerals than most vegetables and fruits [11].

Fiber is an important food component, especially in maintaining a healthy and balanced function of the digestive system [12]. The dietary fiber can absorb water as it passes through the human digestive tract [13]. A study recommends that pregnant women consume $200 \mathrm{~g}$ seaweed/day [14]. The utilization of seaweed can be maximized by diversifying seaweed products [15], such as developing seaweed-based biscuits. Biscuits are one of the food products that are well accepted by the public, including pregnant women, because they taste good, have a long shelf-life, and are convenient to consume anywhere and anytime [16]. Supplementary feeding (PMT) needs to be given as an effort to improve the nutritional intake of the pregnant women. The main requirement for $\mathrm{PMT}$ for pregnant women is that it is well received by these women [17].

Reviews in the literature reveal that functional processed food as an intervention can increase $\mathrm{Hb}$ levels by $0.47-0.96 \mathrm{gr} \%$. The intervention given to the 14-35 years pregnant women was made from various foods such as sweet potatoes, guava juice, red spinach juice, mung bean juice, and Moringa leaves. Meanwhile, in an intervention using seaweed-based foods (K. alvarezii), with a sample of 30 pregnant women for a period of 7 days, the average $\mathrm{Hb}$ levels increased by $1.78 \mathrm{~g} / \mathrm{dl}$ (from $8.94 \mathrm{~g} / \mathrm{dl}$ to $10.72 \mathrm{~g} / \mathrm{dl}$ ) by consuming 100-150 g/dl/day processed seaweed [18]. Research by Dewi et al. (2018) [19] indicated a positive effect of adding seaweed flour on both the iodine content and the panelists' preference for toddlers' complementary foods. A study by Zakaria et al. (2017) [20] also found that the fiber content in Nori from a mixture of $E$. cottonii and $U$. lactuca seaweeds was higher than commercial Nori.

\section{Materials and Methods}

\section{Study design}

The study design was a quasi-experiment pretest-posttest. The study participants were pregnant women with inclusion criteria: Pregnancy age at the first trimester and 20-35 years. They were selected purposively and divided into three groups of intervention. The first group received two pieces of red seaweed (K. alvarezii) biscuits per day, the second group received two pieces of red seaweed biscuit plus Fe tablet $(60 \mathrm{mg})$ per day, and the third group received Fe tablet $(60 \mathrm{mg})$ only or as a control group.

\section{Study location and participants}

This research was conducted Duruka District, Muna Regency, Indonesia, from April to June 2021. The inclusion criteria of the study participants were pregnant women at the first trimester and aged 20-35 years. Meanwhile, pregnant women with a chronic disease were considered drop out. A total of 45 mothers divided into three groups were enrolled.

\section{Ingredients for making red seaweed biscuits (K. alvarezii)}

We used the red seaweed from Lasunapa Village, Muna Regency, Indonesia. Before using them as intervention materials, some treatments are required. The red seaweed is washed, then soaked in freshwater (until the seaweed is completely submerged in water) for $24 \mathrm{~h}$. This process is important to remove the remnants of dirt mixed with seaweed during the removal process from the sea during the harvest process. After soaking the seaweed, it is washed with clean water and then drained and dried until white. This process aims to remove the smell of sea and salt from the seaweed per se. We then wash the seaweed and cut it into small pieces of $\pm 2 \mathrm{~cm}$ to make it easier for the refining process. The seaweed is then crushed using a blender and mixed with other biscuit ingredients in the next stage, including medium protein flour, cornstarch, powdered sugar, milk powder, butter, country chicken eggs, baking powder, and vanilla.

\section{Formulation of making red seaweed biscuits}

The biscuit was formulated using the compositions: $100 \mathrm{~g}$ red seaweed, $100 \mathrm{~g}$ wheat flour, $50 \mathrm{~g}$ cornstarch, 2 egg yolks (40 g), $50 \mathrm{~g}$ butter, $70 \mathrm{~g}$ powdered sugar, $27 \mathrm{~g}$ milk powder, $1 \mathrm{~g}$ baking powder, and $1 \mathrm{~g}$ vanilla. In the next step, we mixed up all ingredients until the biscuit dough was fluffy. Before the dough is baked inside at 160 degrees for $20 \mathrm{~min}$, the biscuits are molded and arranged on a baking sheet.

\section{Nutritional composition red seaweed}

\section{biscuits}

Based on the biscuit formula, it can produce 17 biscuits with $15 \mathrm{~g}$ per piece. The nutritional 
content was calculated using reference of Indonesian composition. One piece of biscuit has $85.8 \mathrm{kcal}$ energy, $12.6 \mathrm{~g}$ carbohydrates, $1.5 \mathrm{~g}$ protein, $3.2 \mathrm{~g}$ fat, $48.1 \mathrm{IU}$ Vitamin A, $0.02 \mathrm{mg}$ Vitamin B1, $0.01 \mathrm{mg}$ Vitamin B6, $1 \mathrm{mg}$ Vitamin C, $21.01 \mathrm{mg}$ calcium, $0.46 \mathrm{mg}$ iron, and $0.16 \mathrm{mg}$ zinc. The biscuits were consumed by the mothers two pieces per day for 8 weeks and they were not allowed to consume them with coffee or tea.

\section{Data collection instrument}

The data were collected using questionnaires, interview guidelines, and observation guidelines from the previous study. Data were collected by trained research assistants for taking bloods and interviews. The tools used were an explanation sheet to respondents, a consent form to become a respondent, a control card sheet for giving red seaweed biscuits ( $K$. alvarezii), a control card sheet for giving blood (Fe) tablets, an observation sheet for hemoglobin $(\mathrm{Hb})$ levels of pregnant women in the intervention and control groups. A $24 \mathrm{~h}$ food recall form was used to collect dietary intake data. Blood test (Easy Touch $\mathrm{GCHb}$ ) was used to measure hemoglobin level.

\section{Statistical analysis}

Univariate analysis was used to determine the distribution of research subjects by calculating the frequency and percentage of each variable. We also performed bivariate analysis using paired sample t-test statistic test, Wilcoxon, one-way ANOVA, and KruskalWallis. ANOVA post hoc test was also performed to examine the difference in the average $\mathrm{Hb}$ levels at the post-test between groups. All statistical analyses were performed using SPSS version 22.

\section{Ethics approval}

The study obtained ethical approval from Health Research Ethics Committee, Faculty of Medicine, the Hasanuddin University (391/UN4.6.4.5.31/PP36/2021).

\section{Results}

Table 1 shows the characteristics of participants in all groups. The average age of the women was below 30 years. Most participants have high education levels in both groups, the red seaweed biscuits plus Fe table and the control group. There are no significant differences of characteristics among groups ( $p>0.05)$.

Table 2 shows the mean changes of $\mathrm{Hb}$ levels in the intervention group compared to the control group. All groups show a significant $\mathrm{Hb}$ level increase with the
Table 1: Characteristics of study participants

\begin{tabular}{|c|c|c|c|c|c|c|c|c|}
\hline \multirow[t]{3}{*}{ Characteristics } & \multirow[t]{3}{*}{ Categories } & \multicolumn{6}{|c|}{ Groups } & \multirow[t]{3}{*}{$p$-value } \\
\hline & & \multicolumn{2}{|c|}{$\begin{array}{l}\text { Red } \\
\text { seaweed } \\
\text { biscuits }\end{array}$} & \multicolumn{2}{|c|}{$\begin{array}{l}\text { Red } \\
\text { seaweed } \\
\text { biscuits } \\
\text { plus Fe } \\
\text { tablet }\end{array}$} & \multicolumn{2}{|c|}{$\begin{array}{l}\mathrm{Fe} \\
\text { tablet (control) }\end{array}$} & \\
\hline & & $\mathrm{n}$ & $\%$ & $\mathrm{n}$ & $\%$ & $n$ & $\%$ & \\
\hline \multirow[t]{3}{*}{ Age } & $20-30$ & 8 & 53.3 & 13 & 86.7 & 12 & 80.0 & \multirow[t]{3}{*}{0.91} \\
\hline & $\geq 31$ & 7 & 46.7 & 2 & 13.3 & 3 & 20.0 & \\
\hline & Total & 15 & 100 & 15 & 100 & 15 & 100 & \\
\hline \multirow[t]{3}{*}{ Education } & Low & 11 & 73.3 & 5 & 33.3 & 5 & 33.3 & \multirow[t]{3}{*}{1.00} \\
\hline & High & 4 & 26.7 & 10 & 66.7 & 10 & 66.7 & \\
\hline & Total & 15 & 100 & 15 & 100 & 15 & 100 & \\
\hline \multirow[t]{3}{*}{ Income } & Low & 7 & 46.7 & 5 & 33.3 & 6 & 40.0 & \multirow[t]{3}{*}{0.35} \\
\hline & High & 8 & 53.3 & 10 & 66.7 & 9 & 60.0 & \\
\hline & Total & 15 & 100 & 15 & 100 & 15 & 100 & \\
\hline \multirow[t]{3}{*}{ Parity } & Primigravida & 3 & 20.0 & 4 & 73.3 & 8 & 53.3 & \multirow[t]{3}{*}{1.00} \\
\hline & Multigravida & 12 & 80.0 & 11 & 26.7 & 7 & 46.7 & \\
\hline & Total & 15 & 100 & 15 & 100 & 15 & 100 & \\
\hline
\end{tabular}

greater changes in the red seaweed biscuits plus $\mathrm{Fe}$ tablet group, followed by the red seaweed biscuits group and the control group $(0.97,0.78$, and 0.60 , respectively, $p<0.05)$. There was also a significant difference between the groups with $p=0.023$. The post hoc test result found a significant difference between red seaweeds biscuits and red seaweeds biscuits with Fe groups compared to the control groups $(p<0.05)$.

Table 2: Hemoglobin changes after the interventions given

\begin{tabular}{|c|c|c|c|c|c|}
\hline \multirow[t]{3}{*}{ Groups } & \multicolumn{2}{|c|}{ Hemoglobin level (mg/dL) } & \multirow[t]{3}{*}{$p$-value } & \multirow[t]{3}{*}{ Changes } & \multirow[t]{3}{*}{$p$-value } \\
\hline & Pretest & Posttest & & & \\
\hline & Mean (SD) & Mean (SD) & & & \\
\hline Red seaweed biscuits & $10.82(0.55)$ & $11.60(0.54)$ & $0.001^{\mathrm{a}}$ & 0.78 & \multirow[t]{4}{*}{$0.023^{\mathrm{c}}$} \\
\hline Red seaweed biscuits & $10.76(0.61)$ & $11.74(0.58)$ & $0.001^{\mathrm{a}}$ & 0.97 & \\
\hline plus Fe tablet & & & & & \\
\hline Fe tablet & $10.58(0.54)$ & $11.18(0.51)$ & $<0.001^{\mathrm{b}}$ & 0.60 & \\
\hline
\end{tabular}

Table 3 shows the effect of the intervention on body weight after the intervention. The study results show that the red seaweed biscuits group has the highest changes compared to the seaweed biscuits plus Fe table and the control groups $(1.07,0.43$, and 0.04 , respectively, $p<0.05)$. Furthermore, the body weight change was significantly different among groups $(p=0.041)$.

Table 3: Body weight changes after the interventions given

\begin{tabular}{|c|c|c|c|c|c|}
\hline \multirow[t]{3}{*}{ Groups } & \multicolumn{2}{|c|}{ Hemoglobin level (mg/dL) } & \multirow[t]{3}{*}{$p$-value } & \multirow[t]{3}{*}{ Changes } & \multirow[t]{3}{*}{$\mathrm{p}$-value } \\
\hline & Pretest & Posttest & & & \\
\hline & Mean (SD) & Mean (SD) & & & \\
\hline Red seaweed biscuits & $48.66(1.54)$ & $49.74(1.70)$ & $<0.001^{a}$ & 1.07 & $0.041^{\circ}$ \\
\hline $\begin{array}{l}\text { Red seaweed biscuits } \\
\text { plus Fe tablet }\end{array}$ & $49.93(3.45)$ & $50.36(3.45)$ & $0.001^{\mathrm{a}}$ & 0.43 & \\
\hline Fe tablet & $48.47(1.55)$ & $48.52(1.54)$ & $0.008^{\mathrm{b}}$ & 0.04 & \\
\hline
\end{tabular}

Table 4 displays the comparison of body weight changes between the three groups at the time of the post-test. The intervention group given seaweed biscuits plus Fe tablets has the highest rank (26.73), while the red seaweed biscuit group was 26.27 , and the control group was 16.00. Based on this, it can be stated that the two types of interventions given might affect changes in body weight.

Table 4: Comparison of changes in body weight measures between groups

\begin{tabular}{llll}
\hline Outcome & Groups & $\mathrm{n}$ & Mean rank \\
\hline Body weight & Red seaweed biscuits & 15 & 26.27 \\
& Red seaweed biscuits + Fe tablet & 15 & 26.73 \\
& Fe tablet & 15 & 16.00 \\
& Total & 45 & \\
\hline
\end{tabular}




\section{Discussion}

Several maternal characteristics were reported including age, education, family income, and parity. However, we found that there were no differences between the two groups for the characteristics indicating that this factor might not affect the result of the study.

The present study found that in the intervention group, where red seaweed biscuits were provided two pieces/day for 8 weeks, there was an increase in the $\mathrm{Hb}$ levels by $0.78 \mathrm{~g} / \mathrm{dL}$. In the intervention group, where two pieces/day of red seaweed biscuits (K. alvarezii) plus $\mathrm{Fe}$ tablets with a dose of $1 \times 60 \mathrm{mg}$ were distributed, there was a $0.97 \mathrm{~g} / \mathrm{dL}$ increase. In the control group (Fe tablets with a dose of $1 \times 60 \mathrm{mg}$ ), the increase was $0.60 \mathrm{~g} / \mathrm{dL}$.

In this study, we calculated the nutrient composition of the biscuits. Each piece of biscuit contains $85.5 \mathrm{kcal}$ of energy, $12.6 \mathrm{~g}$ of carbohydrate, $1.5 \mathrm{~g}$ of protein, $3.2 \mathrm{~g}$ of fat, $48.1 \mathrm{IU}$ of vitamin $\mathrm{A}, 0.02 \mathrm{mg}$ of vitamin $\mathrm{B} 1,0.46 \mathrm{mg}$ of iron, and $0.16 \mathrm{mg}$ of zinc. According to the level of iron enhance nutrients in the products, such as protein, Vitamin A, iron, and zinc, thus this product has the potential to increase the hemoglobin level [9].

Data from this study also showed a significant difference in body weight between the intervention and the control groups after the treatment $(p=0.041)$. It can be assumed that there was a simultaneous effect of the treatment to increase the body weight of pregnant women during the first trimester. A posttest was conducted using the Kruskal-Wallis rank test to compare the average changes in body weight among the observed groups. The results showed that the intervention group of red seaweed biscuits plus $\mathrm{Fe}$ tablets had the highest rank compared to the intervention group of red seaweed biscuits and control groups (26.73, 26.27, and 16.00, respectively).

The findings of this study are in line with a research by Resty (2018) [21] who found that Hb levels in the intervention of Fe tablets and seaweed (Eucheuma sp.) was higher than the control group of Fe tablets $(1.05 \mathrm{gr} \%$ vs. $0.23 \mathrm{gr} \%$ ). The previous study concluded that the combination of Fe tablets and Eucheuma sp. seaweed is probably effective in increasing $\mathrm{Hb}$ levels among anemic pregnant women. Eucheuma sp. seaweed is iron-rich food, which also contains Vitamin B complex, protein for $\mathrm{Hb}$ synthesis, and Vitamin $\mathrm{C}$, which will increase the body's ability to absorb iron in Fe tablets.

A study conducted by Lubis et al. (2013) [15], established that the concentration of seaweed (K. alvarezii) and flour type in wet noodles correlates with $\mathrm{Hb}$ levels in the last trimester. Another study by Rimawati et al. (2018) [18] found that a dietary supplement intervention made from seaweed processed foods could increase $\mathrm{Hb}$ levels in pregnant women.

Research by Kesuma documented that the fiber content per $100 \mathrm{~g}$ wet seaweed (K. alvarezii) is $11.6 \mathrm{~g}$, while in the flour form is $57.2 \%$. In addition to the high fiber content, seaweed also contains micronutrients, including iodine, calcium, potassium, magnesium, and phosphorus. This food also has other compounds (e.g., gelatin, carrageenan, porphyrin, furcellaran, and phycobilin pigments, consisting of phycoerythrin and phycocyanin), which are food reserves rich in carbohydrates and iron [22]. Body weight is closely related to balanced nutrition and a person's healthy lifestyle, either gaining or losing weight. Individual nutritional status determines the amount of energy intake, which is necessary to perform daily activities.

This finding of this study is in line with a study by Soekirman (2013) [23] confirming that a person's nutritional status is very closely related to an increase or decrease in a person's weight. Research conducted by Rehena and Ivak (2019) [24] demonstrated an effect of seaweed substitution on the fiber content in sago cookies. Seaweed is a potential source of dietary fiber as it contains a high dietary fiber content, which is beneficial for health and can prevent various diseases such as cancer, colitis, constipation, and other digestive disorders. It can also be used as an essential ingredient in therapeutic functional foods for obesity, diabetes, hypertension, and coronary heart disease.

Another study found that giving Moringa Oleifera Leaf Powder (MOLP) supplements to pregnant women with moderate anemia in their last trimester for 8 weeks can significantly increase $\mathrm{Hb}$ and cortisol levels compared to IFA supplements. Furthermore, the birth weight was higher in mothers who consumed MOLP than those given IFA [25]. Consuming $15 \mathrm{ml}$ of Moringa honey (MK) or regular honey (MB) before meals every morning for 8 weeks can increase $\mathrm{Hb}$ levels and erythrocyte index (MCV, MCH, and $\mathrm{MCHC}$ ) in the MK and MB groups [26]. Moringa honey has a greater nutritional content than regular honey, so the nutritional intake is higher, but both do not differ in contributing to MDA levels $(105 \pm 50 \mathrm{mg}$ and $89 \pm 46 \mathrm{mg}$, respectively; $p=0.001$ ) [27]

Research by Fitrianti et al. (2021) [28] showed a significant decrease in leukocyte levels after the intervention in the two groups, Moringa honey (MK group) and regular honey (MB group). The same study found a more significant reduction in the Moringa honey group. There was no change in the total lymphocyte count in the Moringa honey or regular honey groups. A study from Kumalasari et al. (2021) [29] confirmed that providing $\mathrm{MH}$ (Moringa honey) to pregnant women can reduce stress and lower cortisol levels better than providing $\mathrm{RH}$ (regular honey).

\section{Conclusion}

The provision of red seaweed biscuits plus Fe can increase the level of $\mathrm{Hb}$ and weight of the first 
trimester pregnant women. A further larger scale study to evaluate the potential of the products as nutrition intervention/program is needed to prevent anaemia among pregnant women, especially in low-middleincome community.

\section{Acknowledgment}

We would like to thank the study participants who have shared their time during this study. We also thank the Head, the Staff, and the Midwives of the Wapunto Puskesmas, who support this study.

\section{References}

1. Manuaba IG. IImu Kebidanan, Penyakit Kandungan Dan Keluarga Berencana Untuk Pendidikan Bidan. Jakarta: EGC; 2010.

2. Nurhaedar J. Peranan Gizi Pada Anemia Ibu Hamil. Makassar: Universitas Hasanudin Makasar; 2012.

3. Rosleyn, Intan P. Strategi dalam penanggulangan pencegahan anemia pada kehamilan. J IImiah Widya. 2016;3(3):1-9.

4. Astriana W. Kejadian anemia pada ibu hamil ditinjau dari paritas dan usia. J Ilmu Kesehatan. 2017;2(2):123-30.

5. Pratiwi AM, Fatimah. Patologi Kehamilan Memahami Berbagai Penyakit and Komplikasi Kehamilan. Yogyakarta: Pustaka Baru Press; 2019

6. Dhakad AK, Pandey VV. Biological, nutritional, and therapeutic significance of Moringa oleifera Lam. 2019;33(11):2870-903. https://doi.org/10.1002/ptr.6475

7. Nugroho BA, Purwaningsih E. Pengaruh diet ekstrak rumput laut (Kappaphycus alvarezii) terhadap kadar glukosa darah tikus putih (Rattus norvegicus) Hipergli kemik. Med Med Indones. 2004;39:54-60

8. Wibowo S, Peranginangin R, Darmawan M, Halim AR. Teknik Pengolahan ATC dari Rumput Laut Eucheumacottonii. Jakarta: Penebar Sadaya Group; 2014.

9. Food and Agriculture Organization. Seaweeds Used as Human Food. Rome, Italy: Food and Agriculture Organization; 2008.

10. Peranginangin $R$, Sinurat $E$, Darmawan. Memproduksi Keraginan dari Rumput Laut. Jakarta: Penebar Swadaya Group; 2013.

11. Ubaedillah. Kajian Rumput Laut Euchema cotonii sebagai Sumber Serat Alternatif Minuman Cendol Instan. Tesis. Bogor: Institut Pertanian Bogor; 2008.

12. Jones PJ, Raeini-Sarjaz $M$, Jenkins DJ, Kendall CW, Vidgen E, Trautwein EA, et al. 2005. Effects of a diet high in plant sterols, vegetable proteins, and viscous fibers (dietary portfolio) on circulating sterol levels and red cell fragility in hypercholesterolemic subjects. Lipids. 40(2):169-74. http://doi. org/10.1007/s11745-005-1372-6

\section{PMid: 15884765}

13. Dwiyitno. Rumput Laut Sebagai Sumber Serat Pangan Potensial. J Squalen. 2011;6(1):9-17.

14. Rahmi R, Nazro Z. Efektifitas konsumsi rumput laut untuk meningkatkan kadar hemoglobin pada ibu hamil anemia. J Endurance. 2018;3(1):195-9.

15. Lubis YM, Erfriza N, Ismaturrahmi, Fahrizal. Pengaruh konsentrasi rumput laut (Kappaphycus alvarezii) dan jenis tepung pada pembuatan mie basah. Rona Teknik Pertanian. 2013;6(1):413.

16. Asmoro LC. Karakteristik organoleptik biskuit dengan penambahan tepung ikan teri nasi (Stolephorus spp). J Teknol Ind Pertanian Univ Brawijaya. 2012;16:52-6.

17. Kemenkes RI. Profil Kesehatan Indonesia 2014. Jakarta: Kementerian Kesehatan; 2010.

18. Eti R. Dietary Supplement Intervention to Increase Haemoglobin Levels in Pregnant Women. J IImu Kesehatan Masyarakat. 2018;9(3):161-70. Available from: http://www.jikm.unsri.ac.id/ index.php/jikm [Last accessed on 2020 Nov 15].

19. Dewi AP, et al. Pemanfaatan Rumput Laut Untuk Meningkatkan Kandungan lodium Pada Makanan Tambahan Balita; 2014. Unnes Journal of Public Health. Available from: http://journal. unnes.ac.id/sju/index.php/ujph. [Last access on 2021 Jun 01]

20. Zakaria FR. Karakteristik Nori Dari Campuran Rumput laut Ulva lactuca dan Kappaphycus alvarezii; 2017. http://dx.doi. org/10.15578/jpbpkb.v12i1.336

21. Noflidaputri Resty. Perbandingan Pemberian Rumput Laut (Eucheuma Sp) Dan Tablet Fe Terhadap Peningkatan Kadar Hemoglobin Ibu Hamil Anemia Di Puskesmas. Menara IImu; 2018.

22. Kesuma CP. Pengaruh substitusi rumput laut (Kappaphycus alvarezii) dan jamur tiram (Pleurotus ostreatus) terhadap daya terima dan kandungan serat pada biskuit. Med Gizi Indones. 2015;10(2):150.

23. Soekirman. Status Anemia Gizi Kini dan Harapan Di Masa Datang. Prosiding. Jakarta: Persatuan Ahli Gizi Indonesia; 2013.

24. RehenaZ, IvakLM. Effect of seaweed substitution on fiber content of sago cookies. J Agribisnis Perikanan. 2019;2019:157-61. http:// doi.org/10.29239/j.agrikan.12.1.157-161

25. Veni H, Marks G, Nontji W, Yus $Y$, Hasni, Hafid R, et al. Moringa oleifera leaf powder supplementation improved the maternal health and birth weight: A randomised controlled trial in pregnant women. Aust $\mathrm{J}$ Herb Naturopathic Med. 2020;32(3):94-101. http://doi.org/10.33235/ajhnm.32.3.94-101

26. Mutmaina R, Hadju $V$, Ahmad M, Nilawati $A$, Hidayanti $H$, Werna N. The Effect of Giving Moringa Honey towards Hemoglobin Levels and Erythrocyte Index in Pregnant Women with Anemia at the Turikale and Lau Health Center, Maros Regency; 2021.

27. Delvica S, Veni H, Nontji W, Nilawati A, Hidayanty H, Ramadany S. The impact of Moringa honey on pregnant women's nutrient intake and malondialdehyde (MDA) levels in Maros Regency. Turk J Comput Math Educ. 2021;12(14):2497-505.

28. Fitrianti M, Hadju V, Nontji W, Nilawati A, Hidayanty $\mathrm{HH}$ Ramadany S. The effect of giving Moringa-honey on leucocyte and total lymphocyte count in pregnant women in Maros district. 2021;12(14):2506-14.

29. Kumalasari F, Hadju V, Nontji W, Nilawati A, Hidayanty H, RS The effect of giving Moringa honey on stress and cortisol levels in pregnant women in Maros Regency. Turk J Comput Math Educ. 2021;12(14):2669-76. 